\title{
The Future of A Fading Chinese Tradition - Hunan Embroidery
}

\author{
Que Zhang \\ Room 101, Building 29, District 2, No. 1 Shaoshan Road (N.), Changsha,Hunan 410011, P.R. China
}

\begin{abstract}
Many traditional forms of Chinese art are facing the risk of becoming extinct. Few people are willing to inherit old, folk craftsmanship due to its hidden nature. Given my passion for Chinese traditional arts, I investigated embroidery's uniqueness and its critical role in China's art history and Cultural Revolution at Hunan Embroidery Research Institute. While traveling to rural towns where Hunan embroidery originated, I interviewed local folk artists. This paper focuses on the role that people's traditional cultural values play in the survival and uniqueness of Hunan embroidery, and the transforming power of modern industrial revolution on the economic status of Chinese folk arts now and in the future. The goal is to raise people's awareness about the importance of appreciating and perpetuating their cultural heritage after examining the status of Human embroidery in today's Chinese society.
\end{abstract}

Keywords: Hunan embroidery, needlework, Chinese ink painting, Chinese politics, Sino-Japanese War, Cultural Revolution, Mao-Ze-Dong, Western oil painting, market status

Submitted Date 22 June 2013

Accepted Date: 27 June 2013

Through the lens of Chinese folk culture, one can critically examine how Chinese politics have contributed to the nature of and style changes in Chinese folk arts. Hunan embroidery, as one of the only two surviving great Chinese embroidery styles today, has overcome major struggles in Chinese history in order to survive as an art form for over 2000 years. As Hunan embroidery gets passed on from generation to generation in this rapidly developing country, Chinese economic growth and labor employment are threatening the market status of Hunan embroidery and its value as a cultural heritage. While China's domestic market demands an increasing amount of westernized decorative art, Hunan embroidery can hardly maintain its cultural authenticity. At the same time, the role of Hunan embroidery in society is diminishing with industrialization, and the younger generation is reluctant to continue this folk art. The Chinese government seems to be the primary source that is sustaining the market of traditional art today. As many uncertainties lie in the future of Chinese politics, what is going to be the prospect of Hunan embroidery?

The Hunan embroidery style, also known as Xiang Xiu, originated in the Hunan province of China, where examples of embroidery have been found which date back more than 2,300 years. ${ }^{1}$ Raising silk worms was a common practice for the Chinese people in the primitive society. People believed that the silk spun by the silkworms was a gift from the divinities, and therefore they always wore clothes made of silk during the harvest season as a way to worship and to show gratitude to the divinities. ${ }^{2}$ During the Han dynasty (206 B.C. to 220 A.D.), the practice of embroidering became common: people's plain silk clothes gradually became embellished with colorful embroidery of flowers, birds, or fish. ${ }^{3}$

Some of the oldest pieces of embroidery were uncovered in the tomb of a queen from the Han dynasty at Ma-Wang-Dui, now a famous tourist site in the city of Changsha, which is the capital of Hunan province. The sophisticated designs of the ancient handkerchiefs and silk gowns in the tomb show that the embroidering skills in Hunan were already well-developed more than 2000 years ago. ${ }^{4}$ Moreover, the flower prints on the silk gown demonstrate the Chinese embroiderers' expertise in dying silk threads during the Han dynasty. ${ }^{5}$ One of the most amazing pieces of embroidery that was unearthed, a silk gown in the empress's grave, weighs only 49 grams. Even with the technology we have today, there has not been a replica that is able to surpass the lightness of that ancient silk gown.

\footnotetext{
${ }^{1}$ Man He, The Art of Hunan Embroidery (Changsha: Hunan Fine Arts

Publishing House, 2007), 35

${ }^{2}$ Xiang-Shu Li, The Making of Hunan Embroidery (Beijing: China Light Industry Press, 1988), p.4

3 Ibid, p.10

${ }^{4}$ Uncovering the Mawangdui Tomb," Hudong Encyclopedia, accessed July 18, 2012,

http://www.hudong.com/mawangdui.

${ }^{5}$ Ibid
} 


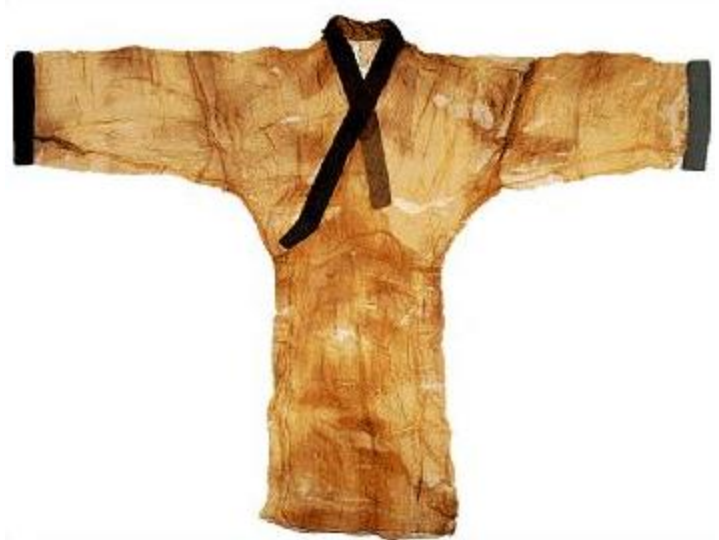

"Ma-Wang-Dui Silk Gown," Hua Xia,

http://www.huaxia.com/zt/zhwh/2004-67/

During the Qing dynasty (1644 A.D. to 1911 A.D.), many new forms of needlework for embroidery were invented with an increasing population of embroiderers. ${ }^{6}$ The lower class women enjoyed embroidery because it beautified their lives. For example, they sewed simple pictures on their fabric shoe tops, waist band, pillow, and hats. ${ }^{7}$ The girls from the upper class, on the other hand, viewed embroidery as a good way to spend their leisure time and to show off their wealth ${ }^{8}$. Before China's last imperial dynasty, Qing, was overthrown in 1911, most of the government garments were elaborated with embroidery, with the emperor's concubines and court officials as the largest consumers. ${ }^{9}$

Because of the large demand of embroidery from the imperial government, various types of needlework were invented in the countryside during the early 1900's. Women from the laboring class started to develop unique styles of embroidery based on their local environments and customs. Hunan embroidery has characteristics of being bold, colorful, bright, and precise-a direct reflection of Hunan people's personality. ${ }^{10}$ Hunan embroidery focuses on topics related to mountains, flowers, and birds, which is influenced by the beautiful mountains and rivers in the province. ${ }^{11}$ The process of creating a piece of Hunan embroidery requires a painter to first sketch an ink design on a Xuan paper. ${ }^{12}$ Then the embroidering part is usually done on transparent chiffon silk: the silk threads are dyed and then soaked in water containing pod nuts (the oil in these nuts tends to make the thread soft and easier to use. $)^{13}$

Currently there are over 600 types of thread colors and 52 kinds of needlework in Hunan embroidery. ${ }^{14}$ The most famous needlework is known as "furry needle", which is widely used for embroidering tigers. ${ }^{15}$ The threads spread out in a star shape, with one end of the threads thin and packed, and the other end thick and loose. ${ }^{16}$ Several layers are required, and each layer uses a set of thinner threads, with the thinnest thread being $1 / 200$ of the thickness of the original thread. ${ }^{17}$ By hiding certain part of the thread, the embroiderer creates an effect that one end of the fur is growing into the animal's body and the other end is fluffy. ${ }^{18}$ To create lifelike tiger's eyes, the embroiderer often has to use a total of 25 shades of yellow, brown, and black. ${ }^{19}$

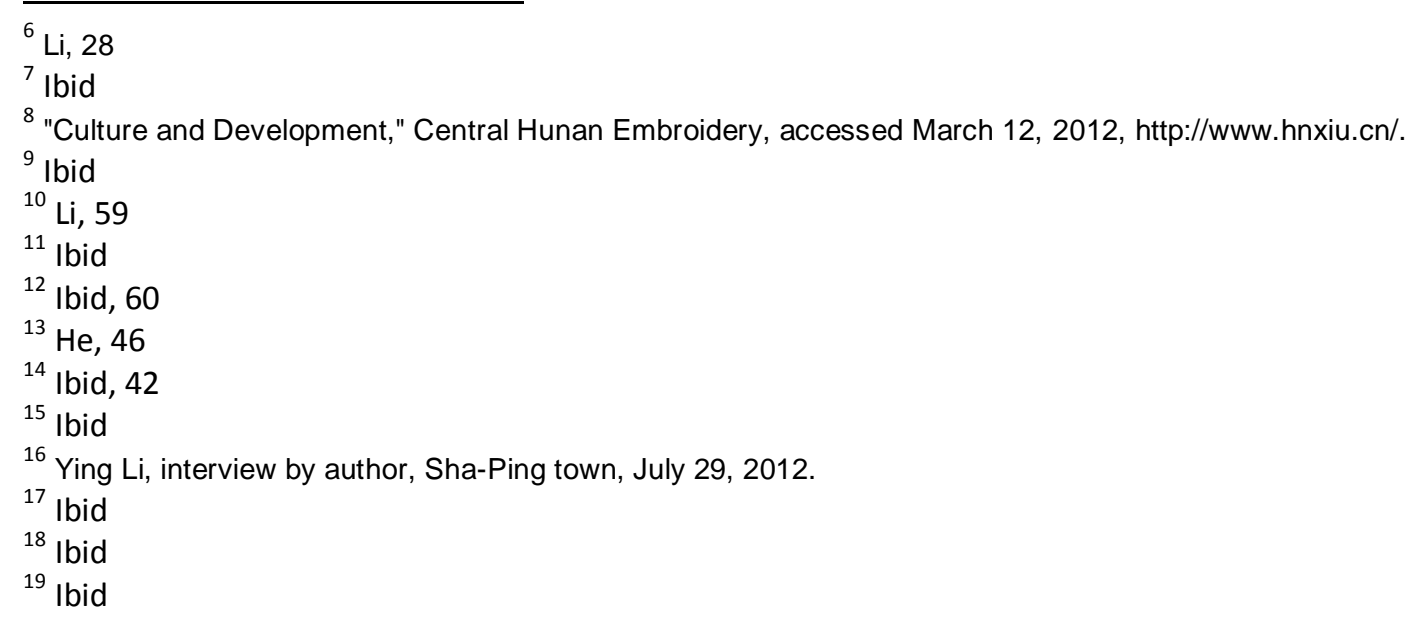




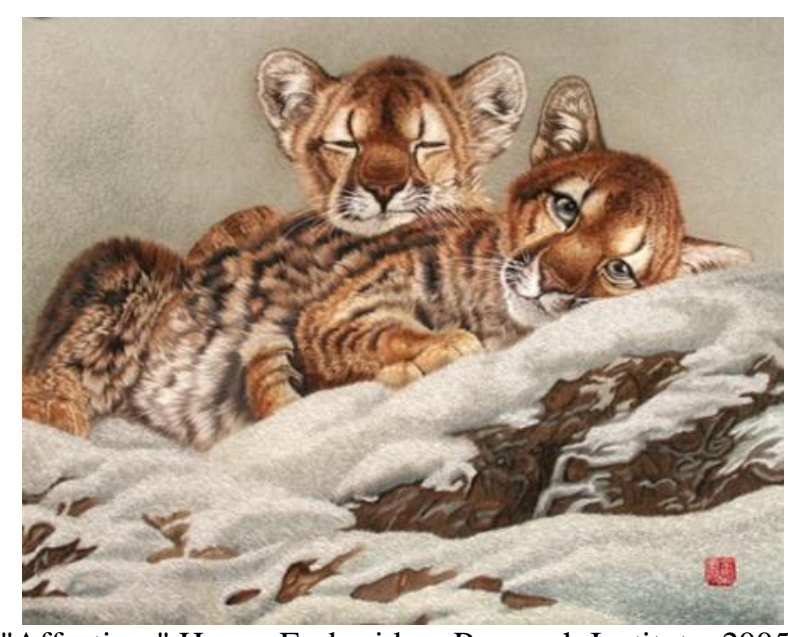

"Affection," Hunan Embroidery Research Institute, 2005,

http://www.hnemb.com/channels/106.html.

Until the opening of Hu Lian-Xian's first embroidery shop in 1911, Hunan embroidery was produced and used at individual homes and was not a commercial item. ${ }^{20}$ Hunan embroidery flourished after it was introduced to the market; many people started to buy everyday utility items that had embroidery as a decoration, such as pillow cases and handkerchiefs. ${ }^{21}$ Soon, Hunan embroidery reached its height by the end of the 1930's, earning over 5,000,000 RMB (approximately 781,250 USD) every year in a total of thirty-six embroidery shops. ${ }^{22}$

However, with the breakout of the Sino-Japanese War in 1937, the majority of Hunan embroidery shops were demolished. Almost all the embroidery was either stolen or ruined. ${ }^{23} \mathrm{~A}$ big fire in the center of the city destroyed most ink painting sketches and finished embroidery works in all the embroidery shops, causing the embroiderers to flee to various provinces of the country. ${ }^{24}$ After the war ended in 1945 , it took only two years for Hunan embroidery to prosper again: as shops recovered after the end of the war, many business owners framed Hunan embroidery as decorations for their shops; friends extended their greetings for each other with Hunan embroidery as a gift. ${ }^{25}$ Many families from overseas came back to China to visit their relatives after the War, and they left China with large amounts of Hunan embroidery to give to their friends from abroad. ${ }^{26}$ Some businesses even gave embroidery works to big banks for getting a loan. ${ }^{27}$ Due to the low cost for the basic tools and raw materials for embroidering, many women began to learn Hunan embroidery at home and then sell their works while making a decent profit. ${ }^{28}$ The employment of the industry went back to 15000 embroiderers who worked in about thirty embroidery shops in $1946 .^{29}$

With the establishment of People's Republic of China in 1949, Hunan embroidery became prosperous again because the new government strongly supported folk arts. ${ }^{30}$ The target market of Hunan embroidery shifted from landlords to the working class, for the Communist Party emphasized the need "to serve the people." ${ }^{\prime 1}$ Lots of daily necessities with embroidery were produced to meet the need of the working class, such as bed sheets, pillow cases, tablecloths, and baby bibs. ${ }^{32}$ The government also kept the prices of embroidery low so that it was accessible for the common folk. ${ }^{33}$

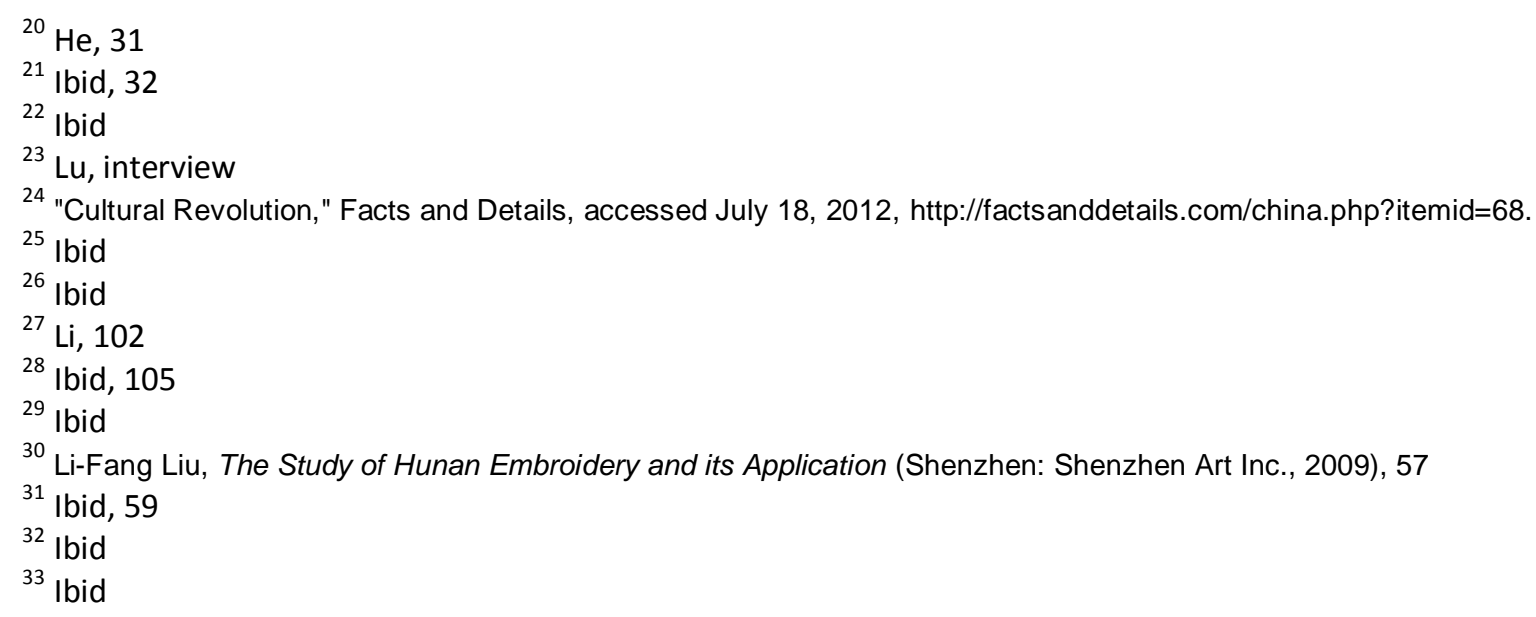


Soon Hunan embroidery, along with many other types of Chinese folk arts, was facing another period of chaos. From 1966 to 1976, the social upheavals during the Chinese Cultural Revolution aimed to create a new society by destroying the "Four Olds" (thinking, habits, culture and customs) ${ }^{34}$ Confucian statues that stood for centuries were labeled as decadent and torn down, priceless vases from the Ming dynasty were shattered, and thousand-year-old Buddhist murals were vandalized beyond repair. ${ }^{35}$ Publications and medias also became government-controlled.

One of the objectives of the Cultural Revolution was to "socially purify" the arts, which included Beijing operas, folklores, and embroidery. ${ }^{36}$ The communist party replaced old movies and Beijing operas with new ones which were allowed to depict only eight revolution-related themes: communist activities during the Sino-Japanese War, civil war with the Nationalists, and the class struggles after the founding of People's Republic of China ${ }^{37}$ Worker committees took over the theater production studios, and even children's puppet theaters were closed down for being counter-revolutionary. ${ }^{38}$ According to Mao-Ze-Dong, "Revolutionary culture is a powerful weapon for the broad masses of the people. It prepares the ground ideologically before the revolution comes and is an important, indeed essential, fighting front in the general revolutionary front during the revolution. ${ }^{, 39}$ To put the idea into action, his wife, Jiang Qing, was in charge of the arts during the Cultural Revolution; she reviewed more than 1,000 operas and concluded that nearly all of them were unacceptable because they dealt with "emperors, officials, scholars and concubines"-ideas from the "Four Olds". ${ }^{40}$ Therefore, Jiang commissioned a series of "revolutionary modern model operas" with heroic figured that displayed socialist virtues. ${ }^{41}$

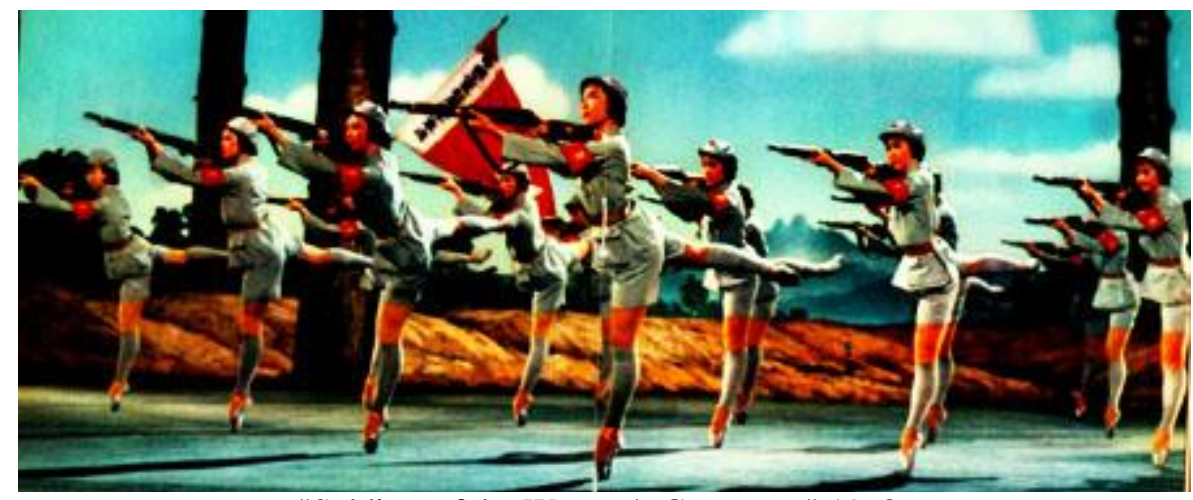

"Soldiers of the Women's Company," 1968,

http://www.nyu.edu/classes/ keefer/twenty/mao1.html

Like the Peking Opera, Hunan embroidery was a tool for political purposes during the Revolution. Before the Cultural Revolution, the themes of Hunan embroidery consisted of animals, flowers, fairy tales, and old legends. ${ }^{42}$ As soon as the Revolution began in 1966, the government criticized this art form because it was seen as part of the "Four Olds", and the production of Hunan embroidery went down to nearly zero. ${ }^{43}$ Eighty percent of the export to the Soviet Union was interrupted, which reduced the amount of profit from Hunan embroidery to 350,000 RMB in 1969- three percent of the profit in $1959 .{ }^{44}$ Many famous embroiderers were sent to villages to do farm work; others were appointed to create artworks for Revolution museums, depicting China's bright future after the Cultural Revolution. ${ }^{45}$ In the entire province of Hunan, there were only 1200 embroiderers and 9 painters left in the embroidery industry. ${ }^{46}$

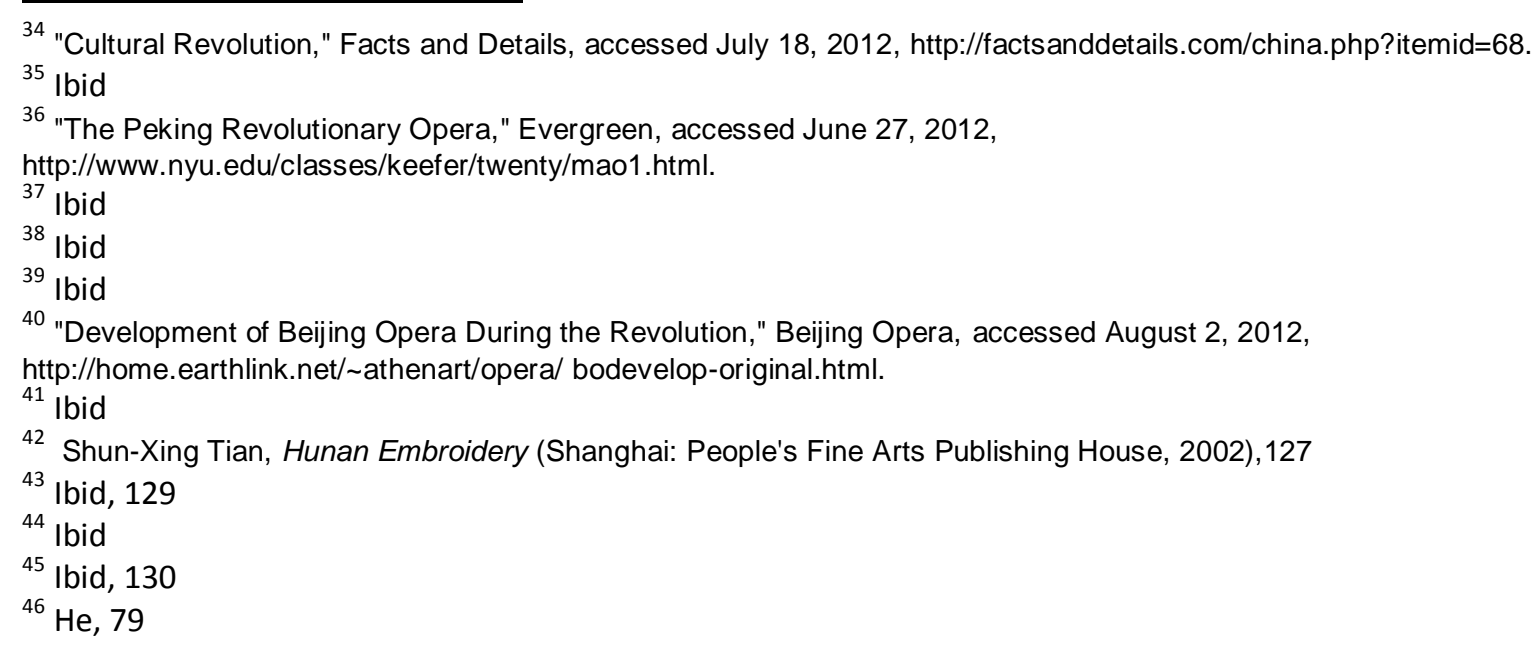


A national renowned painter, Ying-Xiu Yang, deeply felt the impact of the chaos during the Cultural Revolution. He painted a picture of five tigers to be embroidered close to the end of the Revolution, and the painting was sent to Beijing to be approved - a process that all large artworks were required to go through. ${ }^{47}$ Because the Cultural Revolution was against imperialism, Yang was advised to add one or two more tigers so that his design would not be interpreted as a eulogy of the "Five Big Ones" (China, Soviet Union, USA, Britain, and France). ${ }^{48}$ After Yang quickly added the sixth tiger to the painting, the literary and art fields still highly criticized his painting because the aggressive tigers were believed to be a "rebellion against socialism". The painting was also thought to depict Lin-Biao, who was accused of plotting the assassination of Mao. ${ }^{49}$ (The Chinese character of "Biao" consists of three characters of "tiger", and as a result, the critics claimed that Yang's painting of six tigers was worshiping Lin Biao and his son.) Moreover, Yang's traditional Chinese ink painting of plum blossoms was described as "putting the dreams of socialism in darkness", while his imitation of the ancient Chinese painting style was called "turning back the clock for New China". ${ }^{50}$ As a consequence, Yang was forced to leave his art studio and sent to work in the fields. ${ }^{51}$

In order to purge "revisionist thought" during the Cultural Revolution, the government forced the designs of Hunan embroidery to become less ornamental, and to serve political purposes. ${ }^{52}$ For the first time Hunan embroidery included portraits of political leaders and famous soldiers. ${ }^{53}$ Embroidery pieces that portrayed flowers and peonies were still appreciated because they represented the "embroiderers' love for the new government system." ${ }^{54}$ Embroiderers quickly adjusted the themes of Hunan embroidery to celebrate Communism and to show their passion for the bright future, using this old art form to reflect their new life. For example, the piece "Blooming Flowers under the Red Sun," depicted a reddish, golden sun that symbolized the Chinese government. ${ }^{55}$ It has been displayed in many museums and now exhibited in the lobby of the Great Hall of the People in Beijing. ${ }^{56}$

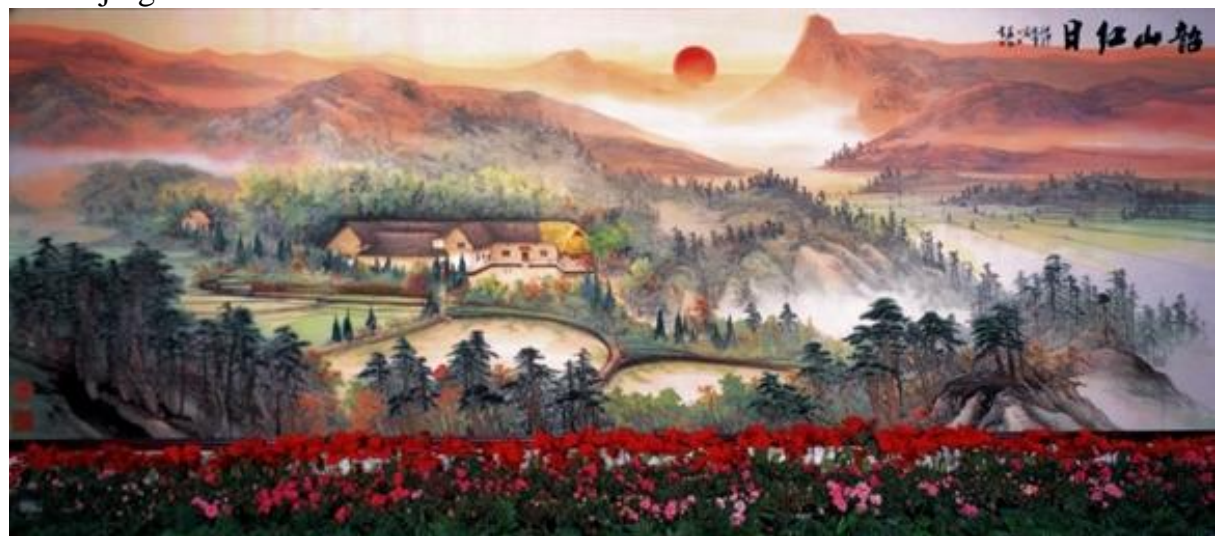

"Blooming Flowers Under the Red Sun," 1972, Great Hall of the People in

Beijing, Museum of Hunan Embroidery Research Institute, http://www.hnemb.com/ channels/212.html.

As soon as the Cultural Revolution ended in 1977, the government gave aid to the Hunan embroidery industry by assigning specific buyers for each embroidery company, which ensures that every embroidery company had a consistent amount of minimum profit. ${ }^{57}$ Hunan embroidery was back to the more decorative style as the government became more focused on the importance of protecting the Chinese cultural heritage. Over thirty renowned embroiderers were invited back to the Hunan Embroidery Research Institute to train hundreds of new employees. ${ }^{58}$ In a few years, double-faced Hunan embroidery was invented in the Hunan

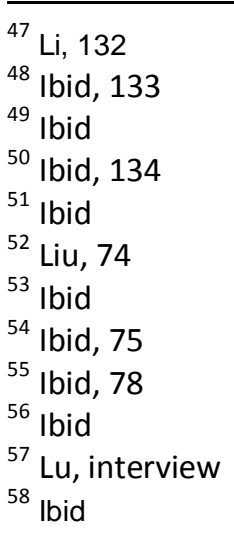


Embroidery Research Institute. ${ }^{59}$ Before the 1980 's, the type of embroidery that required the most technique and experience was double-sided embroidery, which has the same picture on both sides of the silk. Now with double-faced embroidery, there are two different pictures on both sides of the silk. This often requires an embroider on either side of the silk, and when the needle goes through the silk from one side to the other, the person on the other side takes the needle and hides the thread underneath the original threads on her side of the silk. ${ }^{60}$ One of the most famous pieces of double-faced Hunan embroidery is called "Moon Watching": on the one side of the silk, the lady is looking at the moon from the outside of her room; on the other side of the silk, the lady is looking at the moon from the inside of her room. ${ }^{61}$

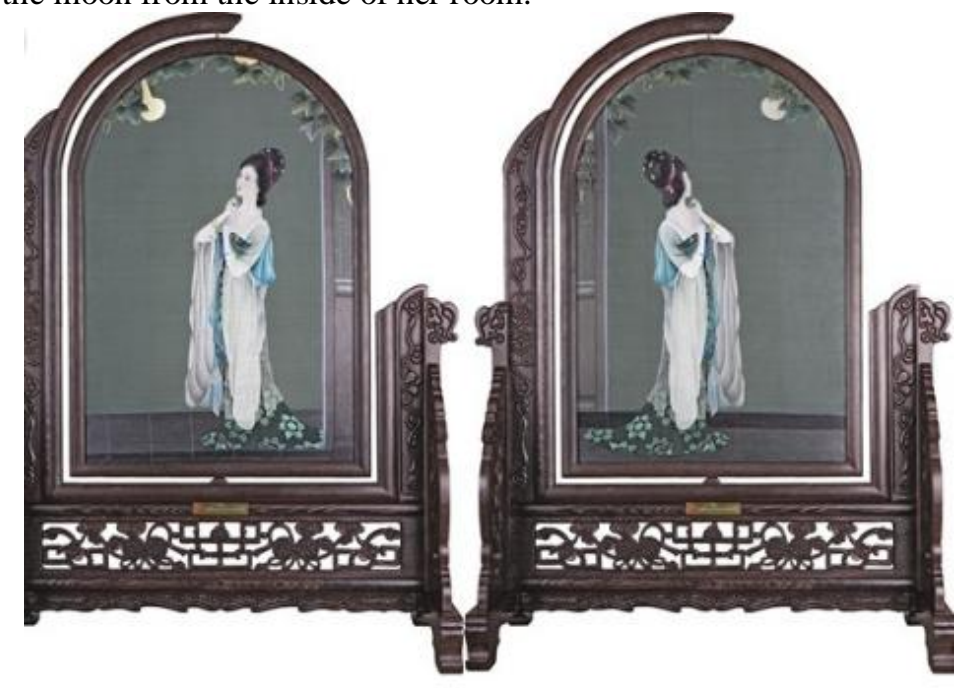

"Moon Watching," 1984, Hunan Embroidery Research Institute, http://www.hnemb.com/channels/212.html.

Nevertheless, starting from the 1990's, the government no longer assigns a given amount of demand for Hunan embroidery for each embroidery company. ${ }^{62}$ Therefore, all the embroidery companies now have to search for their own regular, big customers in the market. For most personally-owned embroidery companies, the main source of profit comes from tourists of other Chinese provinces and Hunan government officials. ${ }^{63}$ Unfortunately, as the China rapidly progresses in modern technology, the occasional new inventions in the traditional handicraft industry are overpowered by the frequent breakthroughs in the mass-producing machine factories. The decreasing number of customers for Hunan embroidery induces a vicious cycle in which lower wage worsens the quality of embroidery works, and it in turn reduces the amount of demand in the domestic market.

In the town of Sha-Ping, where Hunan embroidery first originated in Hunan province, the demand for Hunan embroidery has changed significantly. Sha-Ping occupies $227 \mathrm{~km}^{2}$ only, and it is famous for the twokilometer long street that has embroidery shops on both sides. ${ }^{64}$ During my interview with a middle-aged embroiderer in a small embroidery shop in Sha-Ping, she recalled, "Thirty years ago when my mom was an embroiderer, every morning there would be a truck that comes to the center of our town to buy Hunan embroidery and to place order for more. There were more buyers than embroiderers, but now we have so many leftover embroidery pieces from the past few years." ${ }^{65}$ The items being sold in the Sha-Ping market are usually made from three to five years ago: these are much cheaper than the embroidery pieces that are just finished because the wage of embroiderers is steadily increasing as the Chinese living standard rises. ${ }^{66}$ While the Hunan embroidery shops are always making products for the future, the future of the market for Chinese handmade art is uncertain.

Today, works of Hunan embroidery are made and sold in small shops that usually consist of a manager and five embroiderers. According to my interview with four different managers, employing skilled embroiderers

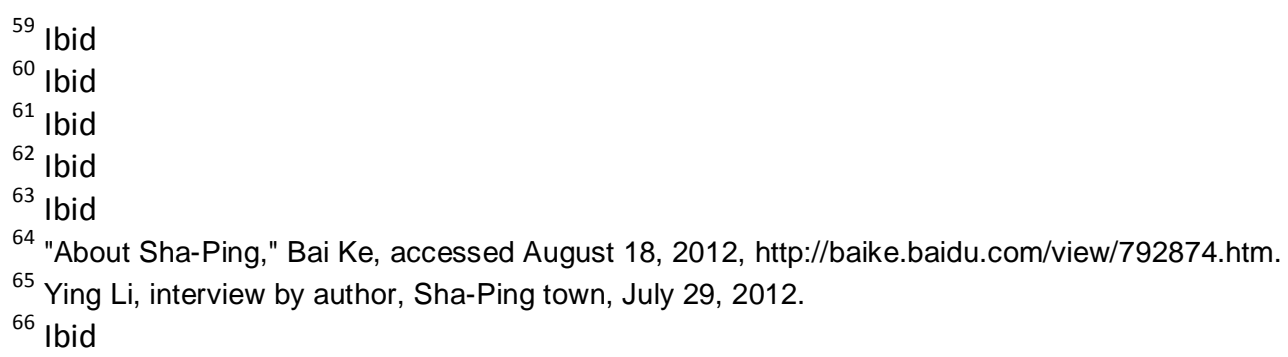


is a lot more difficult now than it was for their parents' generation. ${ }^{67}$ Many young people today prefer blue collar jobs in factories to embroidery because learning about the functions of a machine requires a much shorter training period. ${ }^{68}$ Moreover, the wage for embroiderers is minimal, ranging from 3 RMB (approximately 0.47 USD) per hour to 5 RMB (approximately 0.8 USD) per hour, which hardly covers one person's living costs under the current Chinese living standard. ${ }^{69}$

A small piece of embroidery (ten by ten inch) takes one embroider around one month to finish, and a big piece (eight by four feet) takes three embroiderers at least four months to finish. ${ }^{70}$ When these embroidery pieces are sold in the market, small pieces only cost about 800 RMB (approximately 125 USD) while large pieces cost about 50,000 RMB (approximately 7810 USD). The low economic profit of embroidery shops highly reduces the quality of their finished products. Because the cost for a new design from a famous painter is usually over 80,000 RMB (approximately 12,500 USD), many owners of embroidery shops are reluctant to spend a large amount of money on getting repetitive original designs from famous painters. ${ }^{71}$ Currently, most designs being used for embroidering are either printed from the internet or stolen from other embroidery shops. ${ }^{72}$ This method significantly reduces the cost for producing each embroidery piece, yet it also reduces the artistic value of Hunan embroidery.

From my conversation with a retired embroiderer in the town of Sha-Ping, she said bitterly that now many small embroidery companies are implementing a paying system that is based on the number of specific embroidery works that each person creates. ${ }^{73}$ This impels the workers to not only produce low-quality embroidery but also work on poor designs that they don't like. ${ }^{74}$ She commented, "Embroiderers with low efficiency are kicked out of the workhouse, so there is no room for embroiderers who want to invent new needlework and improve the overall quality of Hunan embroidery as an art."75

As the only government-owned corporation in China's embroidery industry, the Hunan Embroidery Research Institute has more freedom and financial ability to ensure that all of its embroidery products have fine quality. ${ }^{76}$ Compared to the smaller embroidery shops in the market, the Hunan Embroidery Research Institute has the advantage of being supported by the government. Indeed, the higher quality items are coming from the government run facility while the lesser quality goods are from the small family run businesses. Currently, the goal of the Hunan Embroidery Research Institute is to not only increase the economic profit of folk handmade arts but also expand the global influence and market status of Hunan embroidery. ${ }^{77}$

The Institute is forced to abandon some of Hunan embroidery's traditional elements in order to stay competitive in the market for decorative arts. Starting from a few years ago, the traditional elements of Hunan embroidery expanded to include those of Western oil painting, which is an attempt to get more foreigners to purchase Hunan embroidery. ${ }^{78}$ Moreover, the styles of traditional Hunan embroidery have become more modernized and abstract so that they can be suitable for Chinese families who are looking for home decorations: tulips and modern celebrities have replaced peonies and princesses from the Qing dynasty. ${ }^{79}$ The themes of Hunan embroidery are increasingly westernized as more Chinese people are using Western-style furniture and decorations for their houses. Although this method probably can increase the economic profit of folk handmade arts, this trend raises the question of whether or not Chinese folk arts will be able to maintain their cultural authenticity in the future.

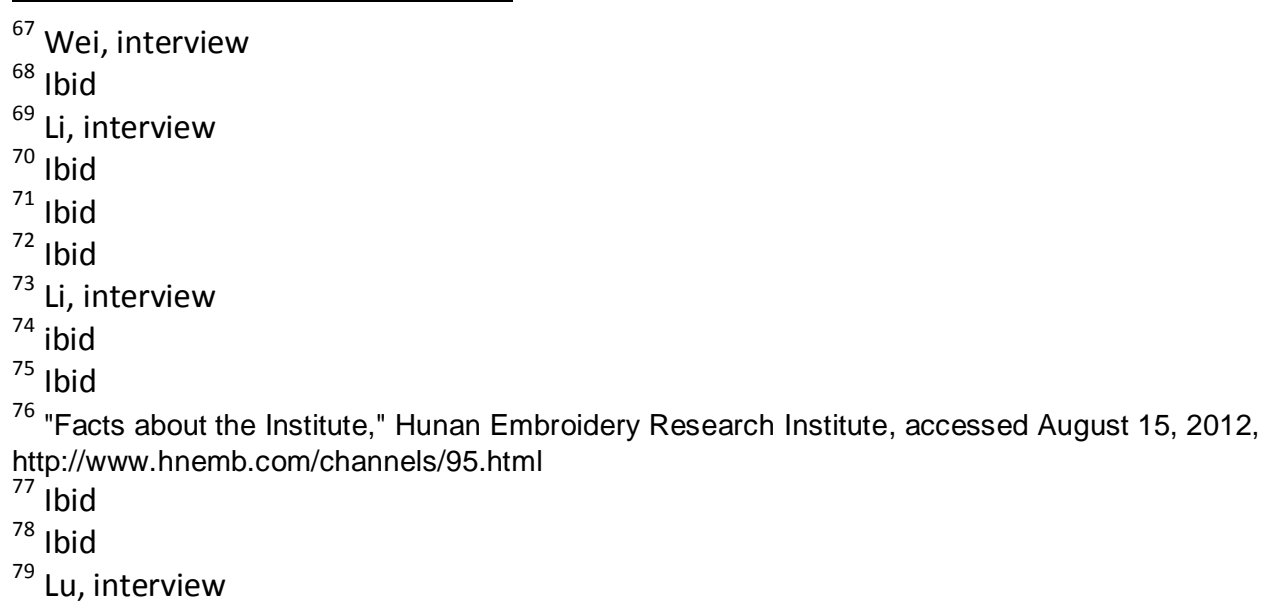




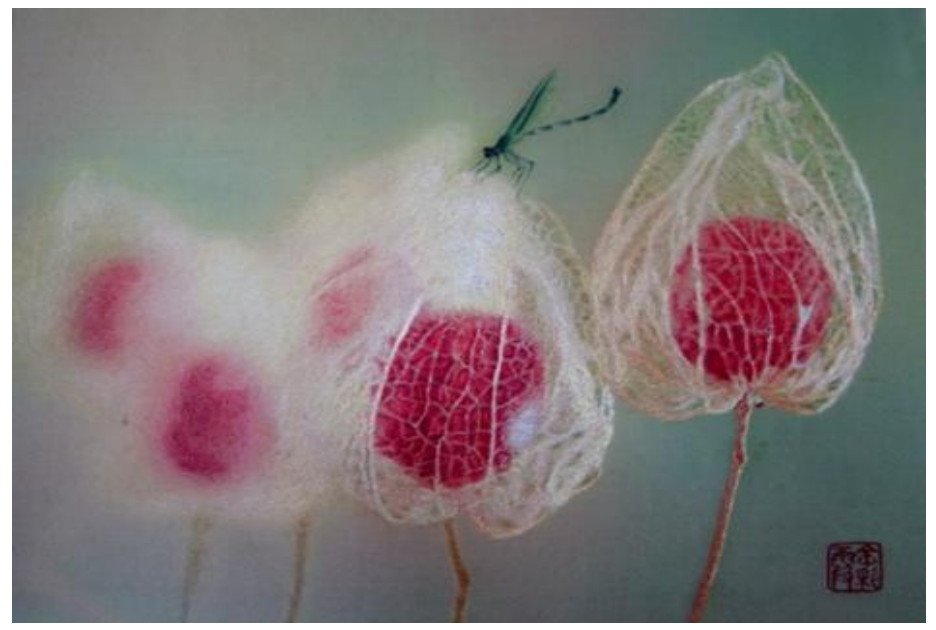

"Sound of Spring," Hunan Embroidery Research Institute, 2011, http://www.hnemb.com/channels/106.html

The Hunan Research Institute has also made some great strides in trying to increase people's awareness of Hunan embroidery's artistic and cultural value. For instance, during the 2012 Shanghai EXPO, there was a project for thousands of tourists to help create a giant piece of embroidery of the Shanghai EXPO under professional Hunan embroiderers' guidance.$^{80}$ This was one of Hunan Embroidery Research Institute's attempts to increase the sales of Hunan folk arts in other provinces and to attract business partners in other countries. ${ }^{81}$ However, the exportation of Hunan embroidery is limited to a few Asian countries due to government restrictions and tax requirements. ${ }^{82}$ Thus as of now, the main consumers at the Hunan Embroidery Institute are still Chinese government officials who often bring Hunan embroidery as gifts for their foreign missions. ${ }^{83}$ Others are government-owned corporation owners who make orders for large embroidery pieces to exhibit in the lobbies of their buildings. ${ }^{84}$

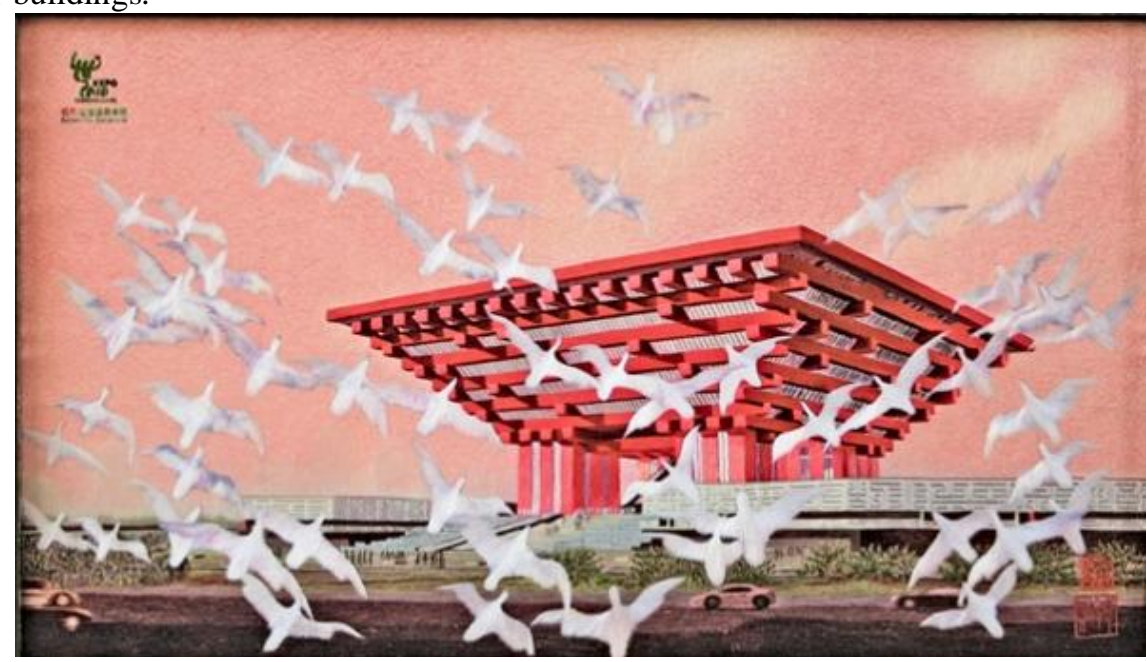

"Peace in China," 2010, Hunan Embroidery Research Institute, Shanghai EXPO Museum, http://www.hnemb.com/channels/108.html.

Despite all the efforts that the Hunan Embroidery Research Institute has spent, the young generations of China today seem to be unwilling to learn folk handmade arts. According to the head of human resources department at the Hunan Embroidery Institute, $\mathrm{Xu}-\mathrm{Hua}$, over the past ten years there has been a significant drop

\footnotetext{
${ }^{80}$ Ibid

81 Ibid

82 Ibid

${ }^{83} \mathrm{Xu}$, interview

${ }^{84}$ Ibid
} 
in the number of applications for embroiderers. ${ }^{85}$ Becoming a good embroiderer requires at least three years of training and practicing, and many young people are reluctant to be embroiderers because of this long period of training that gives no salary. ${ }^{86}$ As an attempt to attract more young workers, the Research Institute started a program with the Hunan Academy of Fine Arts, in which over 300 art students practice Hunan embroidery for two years at the Academy and then are guaranteed a job in the Hunan Embroidery Research Institute after a few months of training. ${ }^{87}$

During my internship in the "Young Embroiderer Workhouse" of Hunan Embroidery Research Institute, I found out that a majority of the seventy girls in the workhouse are from nearby villages, where a decent high school education to get them into colleges is not quite available. All of the embroiderers in that workhouse are around the age of twenty and are graduates from the bridging program between the Hunan Academy of Fine Arts and Hunan Embroidery Research Institute. A few of the girls told me that they had chosen to learn embroidery only because they were guaranteed a job in the Hunan Embroidery Research Institute after graduation.

Hu-Rong, a nineteen-year-old girl from the town of Yi Yang, said, "If I had another chance, I would definitely choose the normal path that people take." ${ }^{88} \mathrm{Her}$ "normal path" referred to attending a public high school and taking the college entrance exam to get into a college, where she could meet people of diverse interests and make a lot more friends. ${ }^{89}$ With a low wage of 1000 RMB per month (approximately 157 USD per month, 1884 USD per year), each person can barely make enough living for herself despite the fact that Hunan Embroidery Research Institute provides housing for all of the embroiderers.

Hunan embroidery, a folk art with craftsmanship that is almost impossible to replace by machines, is again trying to adapt to the changes in the society. However, this time Hunan Embroidery seems to be incompetent to surpass the high efficiency level and low production cost of machine-produced products. The phenomenon that mechanization has diminished the role of folk arts significantly is global. For instance, in the United States, the handmade Amish quilts that were once popular have now became an item of the past-a hidden symbol of a hard working, simple people who place tradition and diligence above all else. ${ }^{90}$ Slowly the Amish people have withdrawn further from the small cities to the last remaining family farms and towns. ${ }^{91}$ Therefore, it is necessary that more people recognize and appreciate the value of traditional handmade arts.

Even though Hunan embroidery successfully survived the chaos during the Sino-Japanese War and the Cultural Revolution, now it is on the verge becoming neglected and forgotten by younger generations because of its low market status in the technology-driven society. Now the Chinese government, after recently declaring "preservation of cultural heritage" as one of its main focuses, serves as the main consumer and stimulator of the $21^{\text {st }}$ century's market for folk art. However, history has shown that the changes in China's political focus have led to both the prosperity and depression of Hunan embroidery. Without the appreciation of handmade folk art from the large Chinese domestic market, will the sole support from the government be enough to revitalize and continue this 2000 -year-old cultural tradition?

\section{References}

[1]. “About Sha-Ping.” Bai Ke. Accessed August 18, 2012. http://baike.baidu.com/view/792874.htm.

[2]. "Affection." Hunan Embroidery Research Institute, 2005. http://www.hnemb.com/channels/106.html.

[3]. "America is Losing Amish Quilters." Amish Quilter. Accessed July 31, 2012. http://www.amishquilter.com/america-is-losing-theamish-quilter/.

[4]. "Blooming Flowers Under the Red Sun." 1972. Great Hall of the People in Beijing, Museum of Hunan Embroidery Research Institute. http://www.hnemb.com/channels/212.html.

[5]. "Cultural Revolution." Facts and Details. Accessed July 18, 2012. http://factsanddetails.com/china.php?itemid=68.

[6]. "Culture and Development." Central Hunan Embroidery. Accessed March 12, 2012. http://www.hnxiu.cn/.

[7]. "Development of Beijing Opera During the Revolution." Beijing Opera. Accessed August 2, 2012. http://home.earthlink.net/ athenart/opera/bodevelop-original.html.

[8]. "Embroidery Museum." Hunan Embroidery Research Institute. Accessed March 13, 2012. http://www.zgxx.hunan.gov.cn/ channels/125.html.

[9]. "Facts about the Institute." Hunan Embroidery Research Institute. Accessed August 15, 2012. http://www.hnemb.com/channels/ 95.html.

[10]. He, Man. The Art of Hunan Embroidery. Changsha: Hunan Fine Arts Publishing House, 2007.

[11]. Hu, Rong. Interview by author, Hunan Embroidery Research Institute Workhouse, August 15, 2012.

[12]. Li, Xiang-Shu. The Making of Hunan Embroidery. Beijing: China Light Industry Press, 1988.

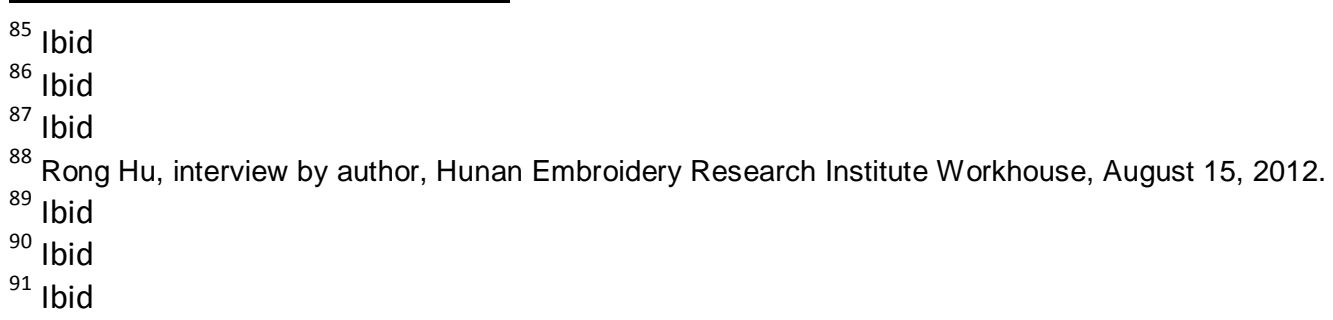


[13]. Li, Ying. Interview by author, Sha-Ping town, July 29, 2012.

[14]. Liu, Li-Fang. The Study of Hunan Embroidery and its Application. Shenzhen: Shenzhen Art Inc., 2009.

[15]. Lu, Xiao-Li. Interview by author, Hunan Embroidery Research Institute, March 13, 2012.

[16]. "Ma-Wang-Dui Silk Gown.” Hua Xia. http://www.huaxia.com/zt/zhwh/2004-67/.

[17]. "Moon Watching." 1984. Hunan Embroidery Research Institute. http://www.hnemb.com/channels/212.html.

[18]. "Mysteries Around the Ma-Wang-Dui Tomb." Hua Xia Jing Wei. Accessed August 5, 2012. http://www.huaxia.com/zt/zhwh/ 2004-67/.

[19]. "Peace in China." 2010. Hunan Embroidery Research Institute, Shanghai EXPO Museum. http://www.hnemb.com/channels/ 108.html.

[20]. “The Peking Revolutionary Opera.” Evergreen. Accessed June 27, 2012. http://www.nyu.edu/classes/keefer/twenty/mao1.html.

[21]. Shanghai EXPO Embroidery . 2010. Museum of Hunan Embroidery, Changsha.

[22]. "Soldiers of the Women's Company." 1968. http://www.nyu.edu/classes/keefer/twenty/maol.html.

[23]. "Sound of Spring." Hunan Embroidery Research Institute, 2011. http://www.hnemb.com/channels/106.html

[24]. Tian, Shun-Xing. Hunan Embroidery. Shanghai: People's Fine Arts Publishing House, 2002.

[25]. "Uncovering the Mawangdui Tomb." Hudong Encyclopedia. Accessed July 18, 2012. http://www.hudong.com/mawangdui.

[26]. “Xiang Embroidery.” Asian Art Mall. Accessed June 8, 2012. http://www.asianartmall.com/xiangembroidery.htm.

[27]. Xu, Hua. Interview by author, Human Resource Office of Hunan Embroidery Research Institute, July 24, 2012.

[28]. Zhou, Min-Na. Today’s Xiang Embroidery. Wuhan: China Crafts and Arts Publishing Inc., 2001. 